\title{
神経麻痺を伴った Deep Neck Infection
}

\author{
吉川 兼人·井澤 一宏・山田一美・稲福 繁*
}

\author{
Deep Neck Infection with Nerve Palsy \\ - Two Cases Report- \\ Kaneto Yoshikawa, Kazuhiro Izawa and Kazumi Yamada \\ (Nagoya Ekisaikai Hospital) \\ Shigeru Inafuku \\ (Aichi Medical University)
}

\begin{abstract}
Due to the advances in antibiotics, severe deep neck infection has recently become rare. We encountered two cases of deep neck infection, one with facial palsy and the other with vocal cord palsy. In this paper, two cases of deep neck infection treated with chemotherapy and surgical drainage are reported. The route of infection, cause of palsy, kinds of bacteria and methods of treatment are discussed.
\end{abstract}

Key words: deep neck infection, facial palsy, vocal cord palsy

緒 言
深頸部感染症は抗生剂の出現する以前は症例 数も多く，死に至ることもかなりあったが，抗 生剂の発達した現在に拈いては比較的稀な疾患 の部類に入っている.しかし，現在においても 一旦発病すれば解剖学的位置関係から常に生命 の危険を伴っていることには変わりがなく，ま た逆に抗生剂によって症状が隠蔽されたり耐性 菌の出現により病態が複雑化しており, 相変わ らず保存的治療法のみならず, 状況によっては 切開排膿が必要なことは以前とは変わっていな い.むしろ抗生剂の効果により，切開を行らか 否か，行らとすればその時期はいつかの判断が 難しくなっている.

表 1 は1989年 1 月から1990年12月までの 2 年
間に当科にて入院加療を要した咽喉頭感染症例 の内訳である. 深頸部感染症は扁桃周囲膿瘍の ような比較的軽症のものから側咽膿瘍のような 重症のものまで計30例あり今回はその中で神経 麻痺を伴った 2 例について若干の考察を加光報 告する.

症例

症例 $1: 58$ 歳, 男性.

初診: 1990年 8 月 9 日.

主訴: 左耳下腺部の疼痛.

既往歴 : 33歳時肺結核, 50歳時クモ膜下出血 (手術)

家族歴：特記すべき事項なし.

現病歴：1990年 7 月17日 カニのカラがのど にひっかかったが翌日に取れ, その後何も症状 
表 1 入院加療を要した咽喉頭感染症例 (1989 1990)

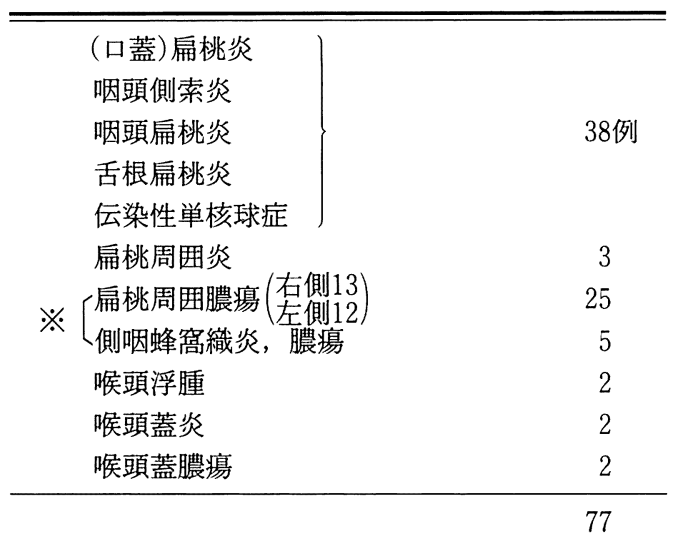

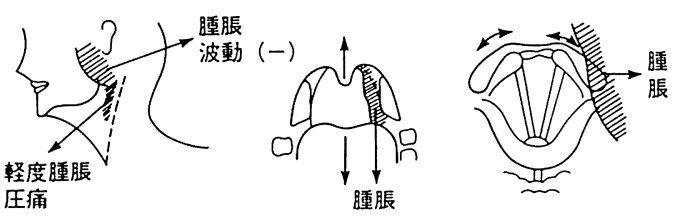

図 1 症例 1 入院時局所所見
がなかったところ，8月 7 日頭痛あり翌 8 日よ り左耳下腺部の疼痛, 発熱 $\left(\right.$ 最高 $\left.38.5^{\circ} \mathrm{C}\right)$ あり, 9 日に来院. 初診時所見は左耳下腺部の軽い腫 脹のみで咽喉頭は良好, Stenon 管からの膿汁 の排出もなく，血液検查と抗生剤の投与をして 帰宅させた。12日に左耳下腺部の疼痛が増強し， 早朝に当院救命センターを受診し鎮痛剤の筋注 を受け，即日当科入院となった．入院時所見は 図 1 の如く左耳下腺部の腫脹と側頸部の一部の 軽い腫脹があり，左顔面の不完全麻㿔があった (facial score 24/40). 咽頭は左の側索部の腫脹 があり，これが下咽頭に至っていたが，喉頭は 腫脹などなく声帯の運動も良好であった. 図 2 はその経過をまとめたものである.

初診時 $\mathrm{WBC} 12,700 / \mathrm{mm}^{3}, \mathrm{CRP} 5.1 \mathrm{mg} / \mathrm{dl}$ 入院時 $\mathrm{WBC} 14,000 / \mathrm{mm}^{3}, \mathrm{CRP} 8.8 \mathrm{mg} / \mathrm{dl}$ 血清アミラーゼ上昇なし ○は中, 下咽頭の， ×は左耳下腺部の腫脹の程度を表している。入 院後セフメタゾール (CMZ)を用いたが, 途中 よりイミペネム(IPM)を中心とし，さらに嫌 気性菌に対して相乗効果を得るためにクリンダ

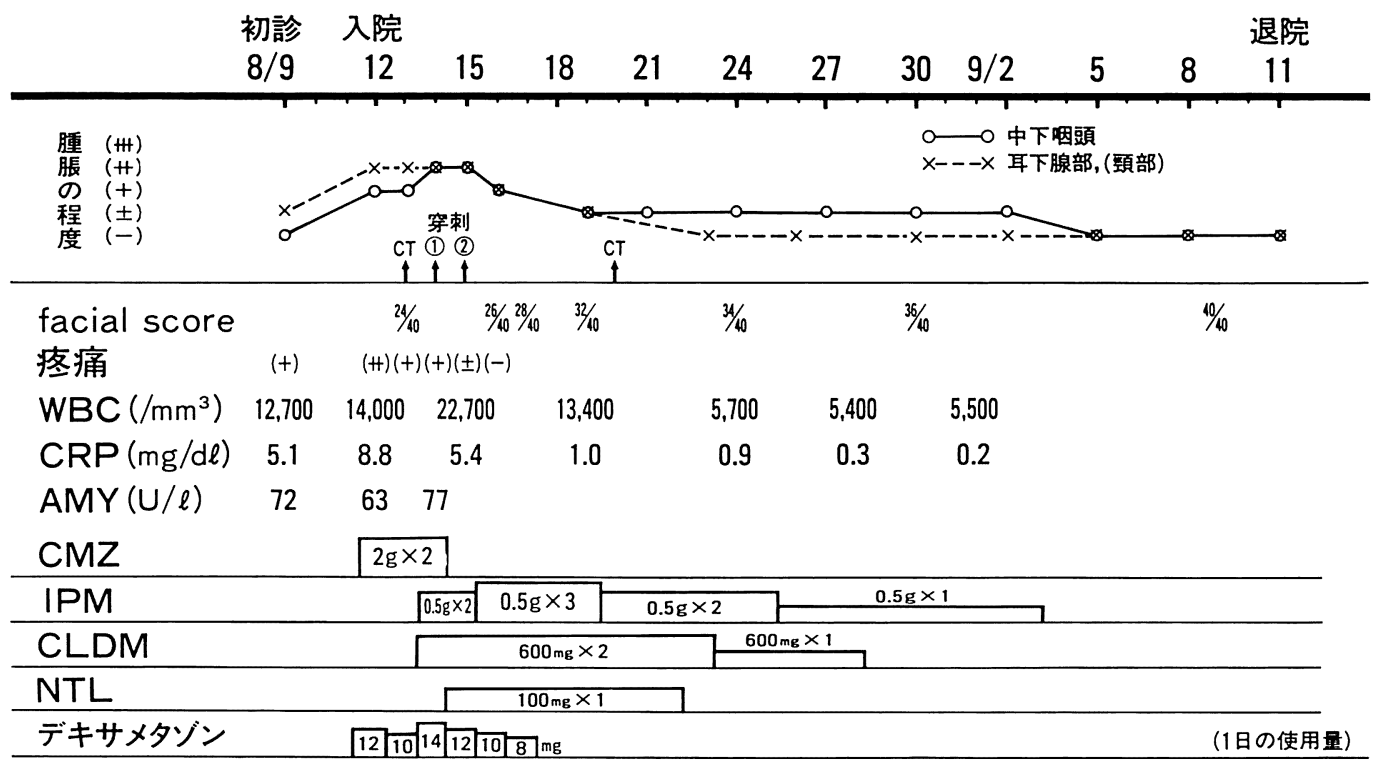

※ 12/14 咽頭穿刺(1)：bloodのみ $\rightarrow \gamma$ 型溶連菌 $(+) ， \alpha$ 型溶連菌(少数)，媒気性菌 $(-)$ 12/15 咽頭穿刺(2)：ひけず

図 2 症例 1 
マイシン (CLDM)を, 緑膿菌に対してさらに ネチルマイシン (NTL), そしてデキサメサゾ ンを使用した. 状況によっては頸部外切開が必 要なことを患者に説明して経過をみていたが, 抗生剂に比較的良く反応し，腫脹は徐々にひき， facial score, 白血球数, CRP とも同様に改善 を認めた。経過中，腫脹した咽頭側索部を 2 回 穿刺した。 1 回は少量の血性渗出液が引け， $\alpha$, $\gamma$ 型の溶連菌が検出された. 図 3 上段は入院翌 日のCT像である。左側咽腔は全体に high density となっており，蜂窩織炎になっている と思われ, 一部咽頭腔に腫脹, 突出している. さらに耳下腺に隣接した部分は low densityを 呈し, 組織壊死または膿瘍形成に至っていると 考兄られる．全体として炎症の範囲は上は口蓋, 下は舌骨の高さまで及んでいた，ちなみに図 3 下段は治療開始後 7 日目のものであるが蜂窩織 炎は改善しつつあり, 筋, 血管の個々の形が明 瞭になってきている。 また咽頭腔への腫脹の突 出はな敃残るものの軽減してきている.

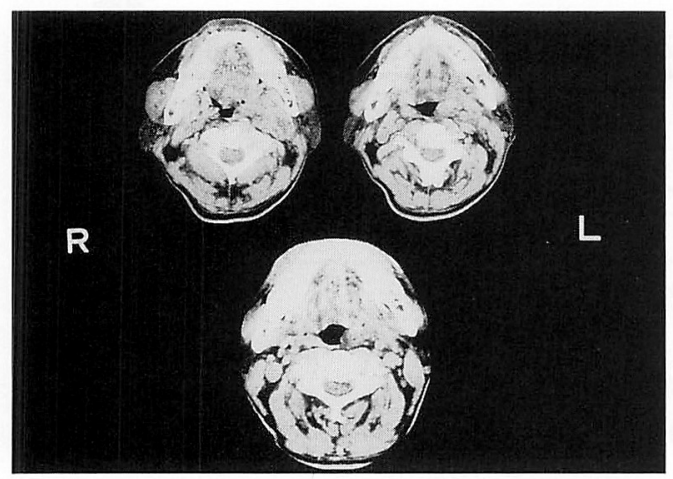

図 3 症例 $1 \mathrm{CT}$ 像
症例 $2 ： 49$ 歳, 男性.

初診：1990年12月17日.

主訴 : 咽頭痛, 嗄声.

既往歴 : 39歳時右扁桃周囲膿瘍

家族歴：特記すべき事項なし

現病歴：1990年12月14日より咽頭痛があり 16 日夕方より疼痛増強し食事がとれず，翌17日に は嗄声も出現したため当院救命センターを受診 し，即日当科入院となった. 所見は図 4 の如く 頸部は左胸鎖乳突筋前縁に沿って腫脹, 圧痛が ある、咽頭は左の側索部に強い腫脹があり,こ れが下咽頭に達していた。喉頭は左披裂部に浮 腫があり，左声帯は傍正中位にて完全に固定し ていた，図 5 はそ午の経過をまとめたものである。 入院時 $\mathrm{WBC} 25,100 / \mathrm{mm}^{3}, \mathrm{CRP} 14.4 \mathrm{mg} / \mathrm{dl}$.

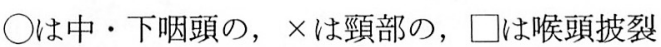
部の腫脹を示している。症例 1 同様 IPM, CLDM，NTL，デキサィタゾンを使用，さらに 入院 2 日目に腫脹した咽頭側索部に縦切開を加 克, 悪臭のある多量の白色膿汁を排出し, 徐々 に改善の方向に向かっていった。喉頭左披裂部 の浮腫は入院 3 日目に改善したが声帯の可動性 の回復はそれよりも遅れ，入院 8 日目に正常な 可動性を認めるに至った。 入院時咽頭側索部の 穿刺で得られたわずかの膿から $\alpha$ 型溶連菌, イ ンフルェンザ菌, 嫌気性菌を検出, さらに翌 18 日の切開時の膿からは緑色連鎖球菌, 嫌気性菌 を検出した。

図 6 は入院時の CT 像である. 左側咽腔全体 が high density で蜂窩織炎になっていると思わ れ，一部咽頭腔に突出した部分には low density area があり，膿瘍を形成していると考光る。 蜂窩織炎の範囲は上は口蓋, 下は声門付近まで
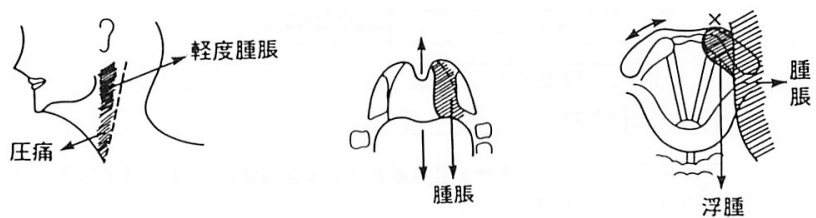

図4 症例 2 入院時局所所見 
及んでいた。

\section{考按}

i ）感染経路と神経麻痺の原因について

直接に深頸部感染症がおこるということはな く，それ以前に表在的な初感染巣があってそこ から深頸部に炎症が波及するのであるが，初感 染巣の代表的な部位として, 咽頭, 口蓋扁桃, 口腔底，歯，唾液腺などの炎症，外傷，先天性 囊胞の感染などが挙げられている1)。しかし実 際に初感染巣を同定するのはなかなか困難なこ とが多いと考光られる。すなわらこれら 2 例の 患者の訴えによると発症から深頸部感染症の完 成までの期間が $2 \sim 3$ 日と推定され，決して長 いものではないからである，同様の症例の文 献2) 6) では発症から数日汪どで, 痛みがひど くなり来院し，そのときはすでに深頸部感染症 の状態になっているものもかなりあり，また逆 に急性扁桃炎などがぐずつき，こじれて次第に 深頭部感染症へと移行していくといら報告もみ られた。つまり，咽頭炎，扁桃炎などといった 初感染巣のみで炎症が終るのか，つついて深頸 部感染症に移行するのかは最初のごく短期間の
らちに細菌の力, 患者本人の年齢, 体力, そし て糖尿病等合併症の有無などの要素もまじえ決 まっていくよらな印象を受ける。佐藤ら7は， 同程度の重症の深頸部感染症症例を 2 例報告し ているが，そのらちの 1 例は肝硬変様の肝機能 障害を有して抢り，各種の治療にもかかわらず 悪化の一途をたどって死亡に至り，他の合併症 のない 1 例は治癒したといら症例を報告してい る。また著者らは以前，糖尿病を基礎に持って いて深頸部感染症が非常に難治であった症例を

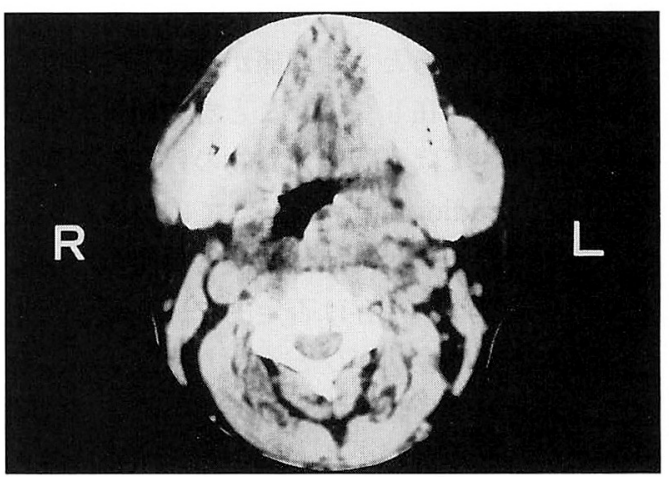

図 6 症例 $2 \mathrm{CT}$ 像

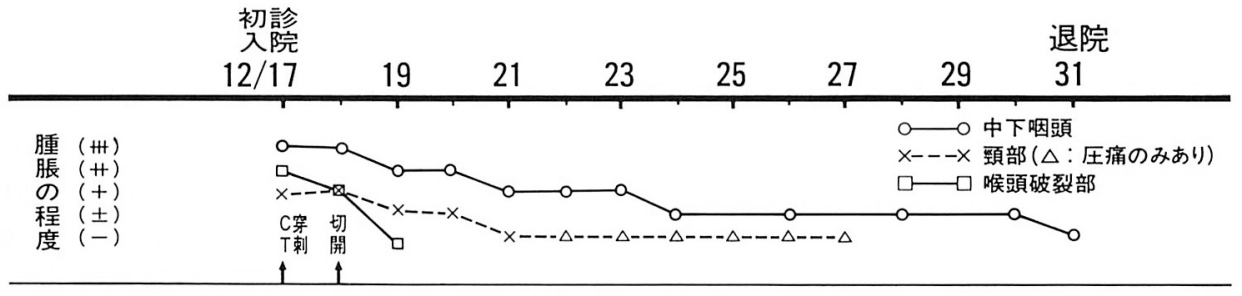

左声帯の可動性 $(-)(-) \longrightarrow$ 徐々に改善

疼痛 (H) (H) $(+)(+)( \pm)( \pm)( \pm)(-)$

$\begin{array}{lllll}\operatorname{WBC}\left(/ \mathrm{mm}^{3}\right) & 25,100 & 23,20017,10013,000 & 12,900 & 9,100\end{array}$

CRP $(\mathrm{mg} / \mathrm{d} \ell) \quad 14.4 \quad 11.0 \quad 4.7 \quad 2.2 \quad 0.2$

\begin{tabular}{|c|c|c|c|c|}
\hline IPM & {$[0.5 \mathrm{~g} \times 2$} & $0.5 \mathrm{~g} \times 3$ & $0.5 \mathrm{~g} \times 2$ & ברואי0.5g \\
\hline CLDM & 6 & $600 \mathrm{mg} \times 3$ & $\overline{600 \mathrm{mg} \times 2}$ & 617 \\
\hline
\end{tabular}

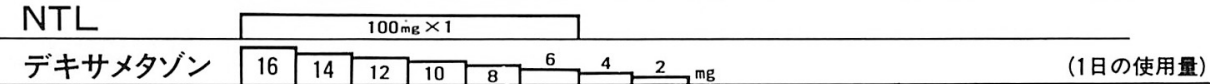

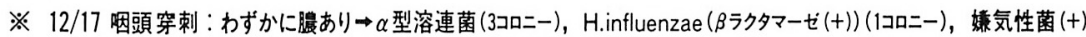
$12 / 18$ 咽頭切開：排膿あり $\rightarrow$ 緑色連鎖球菌 (少数), 嫌気性菌 $(+)$

図 5 症例 2 
経験している. 今回の 2 症例に执いて(1)発症か ら深頸部感染症に至るまでの期間が非常に短い こと(2)来院したときにすでに深頸部感染症にな っていることが感染経路の同定を困難にしてい ると考える. 各々の症例を検討してみると, 症 例 1 はカニのカラがのどにひっかかったといら 既往がある. しかし翌日に取れその後何ら症状 なく，約 3 週間たってはじめて諸症状が出てお り, 創傷からの感染にしては少し日数がたちす ぎている感がある. 同様に高橋ら ${ }^{8)}$ は患者自ら がささった魚骨を引き抜いたあと 5 日後に深頸 部感染症を怙こした症例を紹介しているが，こ れは引き抜いたあとも咽頭痛が持続して括り， 炎症が続いて存在していたことを物語っている. 本症例においては入院後も異物の残存の有無を computed radiographyなどにて確かめたが見 あたらなかった。 また，消炎後も再発がなかっ たことから異物の残存は否定的である．また本 症例は本格的に症状がひどくなり入院する 3 日 前に外来を一度受診しているが，このときは咽 喉頭はまったく良好であり，また咽頭痛は訴え ていないので咽喉頭炎, 扁桃炎からの続発も考 えにくく, 初感染巣は不明である. 顔面神経麻 痺は深頸部感染症の炎症が耳下腺の間質または 顔面神経管内に波及し神経炎を扎こし，麻痺を きたしたものと考える. 側頭骨外顔面神経麻瘏 の原因として丘村9)，戸川ら 10)，戸川11) は化膿 性耳下腺炎もあげているが，麻疩発症の確率は 稀であるとして招り，また本症例では耳下腺の 腫脹はあったものの血清アミラーゼの上昇はな く，また Stenon 管からの膿の排泄もなく，耳 下腺炎から深頸部感染症を扣こしたとは考皇に くいと思う。

症例 2 は来院の 3 日前より軽い咽頭痛があり, 初期感染巣として咽頭, 扁桃の炎症が疑われる が, 確実なものとはいえない. 左声帯の運動麻 痺は，披裂部の腫脹によるものと迷走神経また は反回神経の麻痺によるものの 2 者が考兄られ る. 佐藤ら7)は下咽頭側壁から披裂部にかけて の強い腫脹のため声帯の可動性が悪くなったと
思われる症例を紹介しているが，この症例 2 は 披裂部の浮腫が完全にとれてから声帯の可動性 が完全に回復するまでに 5 日間ほどかかってお り, むしろ後者の迷走(または反回) 神経の麻痺 によるものではないかと考えている，迷走神経 の麻痺は荒牧 ${ }^{12)}$ が述べているように側咽腔の 強い炎症により直接神経炎を抏こしたことも考 えられるが，寺山ら ${ }^{13)}$ が Villaret 症候群 (XX, $X, X I ， X I I$ 脳神経麻痺十頸部交感神経麻痺)に ついて発表しているょうにこの位置では他の脳 神経などの麻㽻があってもよさそらなのでさら に末梢のレベルの可能性が高い．またこういう 状況であるからウイルス感染によるものも否定 できないが，今回はウイルスについては検索が してないためはっきりしたことは言及できない。

ii ) 検出菌

文献14)15) では好気性菌として溶連菌, 黄色 ブドウ球菌, インフルェンザ菌, 肺炎球菌など がよく検出されるとして挙げられている．2 症 例の好気性の検出菌は溶連菌, インフルェンザ 菌などであった．そして大切なのは嫌気性菌で あり，文献ではPeptostreptococcus などがあ るとされている. 症例 2 において切開に際して 悪臭のある膿汁が流出し，同定まではされてい ないが嫌気性菌が 2 回にわたって検出されてい る．伊藤 ${ }^{14)}$ は膿瘍が形成されているときは嫌 気性菌の検出頻度が高いと述べているが，我々 は扁桃周团膿瘍のような比較的軽症の部類に入 る深頸部感染症でも穿刺, 切開に扣いて膿汁の 有無にかかわらず嫌気性菌が関与している可能 性が充分に考えられることから嫌気性菌に有効 な抗生剤も加えるように配虑してきている。ま た最近の傾向として, 抗生剤の効果が充分得ら れないとき， $\beta$-ラクタマーゼ産生菌の存在を考 慮に入れた方が良いと考える。

iii）治 療

適切な抗生剂の投与と, 外科的処置の 2 者が この疾患の主な治療法である. 抗生剂の投与は 必要と思われるものを短期間に集中的に投与す べきで，漫然と長期間投与していては効果が十 
分に出ないばかりか，菌交代現象がおこってく る危険性がある．前述したような比較的検出さ れやすい菌に照準をあて抗生剤を選択する訳で あるが，嫌気性菌対策は常に考慮に入れた方が 良いことは先に述べたと拈りである.IPM と CLDM， NTL の組み合わせは抗菌スペクトル 上で重なっている部分もあるが相乗効果をねら ったためである、ステロイド剤は糖尿病, 胃潰 瘍などステロイド剤禁忌の疾患がない症例に対 し局所の腫脹を退かせたり, 疼痛を和らげたり するために使っている. 腫脹がとれれば部位に よっては呼吸困難の危険性を回避でさるし，ま た疼痛を軽減させられば食事摂取が可能となり， それが食事摂取不能 $\rightarrow$ 体力低下 $\rightarrow$ 相対的菌力増 進(感染の悪化)といら悪循環を断ち切ることが できる、ステロイド剤の投与も長期間使うこと によって真菌類が増殖し他の合併症のもととな るが短期間で打ち切ればまず問題はない，さて 次に外科的処置であるが，時には 2 つの “切開” が必要となることもある１つは膿瘍形成時の 切開排膿であり, も5 1 つは呼吸困難時の気管 切開である. いずれも切開の時期が問題となる. 膿瘍の切開排膿は内切開と外切開の 2 種類があ り, 前者は扁桃周囲膿瘍の切開などがそれに相 当する. 咽頭側索の膿瘍形成においても内切開 による排膿は効を奏する. 内切開をとるか外切 開をとるかは膿瘍の存在部位, 進展範囲により 決定される. 副咽頭間隙を茎状突起より前を前 区，後を後区と分けている16) が，膿瘍が前区 にあれば内切開, 後区にあれば外切開が良いと されている17). 症例 1 は後区に, 症例 2 は前区 に組織壊死ないし膿瘍形成といった所見がみら れ，2例とも咽頭側索部の腫脹があった．症例 1 は 2 回にわたる咽頭側索部の穿刺でも膿が引 けず内切開をしなかったが, 症例 2 は内切開に より排膿し，急速に所見の改善をみている。ま た症例 1 は抗生剂に良く反応して側索部などの 腫脹がよく退いたため外切開をためらったが CT で壊死状の所見があり，たとえ膿貯留がな くとも局所を外切開により開放し空気にさらし
た方が，治瘉期間については短縮化できたので はないかと考学る，抗生剤の発達により，それ らの有効利用によって症状, 所見が軽減化する 一方，隠蔽化されるといら点は問題である。た だし外切開は最終的に頸部に切開創の瘢痕が残 るため，軽症なものでも切れば良いといらもの ではない。八木ら ${ }^{18)}$ は CT が炎症部位, 膿瘍 の有無を正確に判断する上で不可欠であり, 膿 瘍が形成されていれば切開排膿，蜂窩織炎で抗 生剂の効果の悪いものは切開と述べている。 た小林ら ${ }^{19)}$ は, 全身状態, 気道確保の状況を みて切開排膿の時期を決定するとしているが， 著者は膿瘍形成の有無のほかに，切開するか否 かのもら 1 つのカギとして呼吸困難をきたす要 素があるか，縦隔へ波及するかどらかといった 点を重視したい，下咽頭喉頭の腫脹をきたし， 呼吸困難の危険性が高ければ積極的に消炎を目 的とした切開を行らべきであると考学る．症例 2 のように一側の声帯の可動性が固定していて, もしもさらに局所の腫脹が加わってくれば呼吸 困難の危険性は大であり，積極的に消炎を目的 とした内側または外側の切開をしなければいけ ないことは言うまでもないことである，次に気 管切開であるが，下咽頭，喉頭の腫脹の著しい 症例, 声帯の麻疩により声門が狭くなっている 症例は要注意であり，手術適応を考劣ねばなら ない、喉頭とくに披裂部の強い浮腫は吸気時の 吸い込及現象で呼吸困難がひきおこされること があるので危険なケースについては本人，家族 に呼吸困難に陥る可能性についてあらかじめ十 分な説明が必要であるし，頻回に診察をし，ま た動脈血ガス分析の值も参考にして早目に手術 への対応をとることが肝要である．また事前に 頸部から胸部にかけての単純写真をとり, 気管 が膿瘍等で圧排されて正中から偏位しているこ とがないか，緊急時にあわてることがないよう あらかじめチェックして报くことも大切と思わ れる。

最後に炎症局所の治療効果があらわれてくる 過程をどう判定していくかという点がある，咽 
喉頭, 頸部の腫脹は視診, 内視鏡による観察, 触診などで把握できるが，直接視ることのでき ない深頸部の部分はCRP を指標に用いるのが 良いと思う。CRPは白血球数, 血沈に比し炎 症の強弱を鋭敏に反映しており，すばやく変動 するため全体の炎症の改善をみるには良い検査 法と考える. 白血球数は薬剂(特にステロイド 剤によよっても左右され，あまりあてにはなら ないし, 血沈は変動が遅く, 実際に CRP が正 常範囲に入ってからさらに $1 \sim 2$ 週間遅れて正 常化している. 他に CT で局所の状況の変化を みるのも非常に良い方法と思らが被曝の問題も あり，また必要なときにすぐにとれるものでも なくあまり頻回に行えないといら久点がある.

$$
\text { まとめ }
$$

神経麻痺を伴った深頸部感染症 2 症例を報告 し, この症例のもつ問題点(感染経路, 細菌, 治療)について若干の文献的考察を加え私見を 述べた。

\section{謝 辞}

稿を終えるにあたり，御校閱を賜りました愛知医 科大学耳鼻咽喉科学教室瀧本勲教授, 石神寛通教授 に深謝致します。

な括この論文の要旨は日耳鼻第66回東海地方部会 連合講演会(1991年 9 月15日, 岐阜)にてロ演した.

\section{参考文献}

1）宮川晃一：深頸部膿瘍の診断と応急処置. JOHNS $7: 121 \sim 124,1991$.

2) 川島 真, 富樫孝一, 中野雄一: 深頸部感染症 の 2 症例. 耳鼻 $30: 10 \sim 14,1984$.

3）温 永明, 黒田建彰, 石川 哮: 副咽頭間隙膿 瘍の 1 症例. 耳喉 $58: 575 \sim 579,1986$.

4）河野嘉彦, 高橋宏幸, 串田伸一, 他: 副咽頭間 隙膿瘍の一症例. 耳鼻臨床 補 $27: 101 \sim 105$, 1988.

5）佐藤公則, 大久保洋, 栗田茂二朗, 他 : 急激な
経過をとり死亡した Deep neck infection の 1 症例. 耳鼻 $34: 1173 \sim 1177,1988$.

6）朝比奈紀彦, 白倉真人, 藤谷 哲, 他: 最近経 験したDeep neck infection の 5 症例. 耳展 $32: 99 \sim 104,1989$.

7）佐藤 充, 野々村直文, 中野雄一, 他: 対照的 な転帰をたどった側咽膿瘍の 2 症例.耳鼻 34 : 6〜12, 1988.

8) 高橋光明, 内藤義弘, 中村 晃, 他: Deep neck infection $の 6$ 症例. 耳喉 $56: 599 \sim 604$, 1984.

9）丘村 熙: 化膿性耳下腺炎. JOHNS $2: 371 \sim$ 375, 1986.

10）戸川 清, 北村 武：唾液腺と顔面神経. 耳喉 $43: 827 \sim 835,1971$.

11）戸川 清 : 側頭骨外顔面神経麻痺. JOHNS 3 : 417 422, 1987.

12）荒牧 元: 深頸部感染症. JOHNS $4: 575 \sim 580$, 1988.

13）寺山吉彦, 安藤敬子, 繁 英一 : Villaret 症候 群を呈し出血死に至った慢性側咽腔炎の 1 例. 耳喉 $45:$ 565 569, 1973.

14）伊藤博隆：扁桃周囲炎 - 扁桃周囲膿瘍. JOHNS $4:$ 1452 1455, 1988.

15）中島 務, 柳田則之, 丹羽英人, 他 : 扁桃周囲 膿瘍に拈ける検出菌と治療. 耳鼻臨床 83 : 1743 1749, 1990.

16）寺山吉彦：側咽膿瘍と咽後膿瘍. 耳喉 $52: 751$ $\sim 756,1980$.

17）後藤昭信：副咽頭間隙膿瑒の 3 症例. 耳鼻臨床 補38: 157 162, 1990.

18）八木昌人, 田山二朗, 市村恵一 : Deep neck infection. 耳鼻 $35: 1 \sim 6,1989$.

19）小林武夫, 内藤 玲 : 深頸部感染症 Deep neck infection. 日耳鼻専門医通信 $28: 14 \sim 15,1991$.

$$
\left(\begin{array}{c}
\text { 別刷請求先 : 吉川兼人 } \\
\mathbf{T} 480-11 \text { 愛知県愛知郡長久手町 } \\
\text { 大字岩作字雁又 } 21 \\
\text { 愛知医科大学耳鼻咽喉科学教室 }
\end{array}\right)
$$

